\title{
Sensitivity of Xanthomonas campestris pv. citri and Some Other Phytopathogenic Bacteria to Superoxide, Ultraviolet Light and Methylviologen
}

\author{
Noriyuki DokE* and Toshihiro ShiBata*
}

\begin{abstract}
Incubation of Xanthomonas campestris pv. citri, pv. campestris, pv. pruni, and pv. vesicatoria with an extracellular $\mathrm{O}_{2}^{-}$generating system, xanthine-xanthine oxidase (XOD) reaction mixture, resulted in extensive death of these bacteria. However, other tested bacteria, Agrobacterium tumefaciens, Erwinia herbicola and Corynebacterium michiganense were more tolerant to the $\mathrm{O}_{2}^{-}$generating system. The toxicity of the $\mathrm{O}_{2}^{-}$generating system to each bacterium was positively correlated with sensitivity to ultraviolet light irradiation, and negatively correlated with the activity of the bacterial superoxide dismutase (SOD). Killing of $X$. campestris pv. citri by the $\mathrm{O}_{2}^{-}$generating system occurred with a linear dependency on log concentration of XOD. Exogenously added SOD partially negated the effect with a linear dependency on the log concentration. $X$. campestris pv. citri was also highly sensitive to methylviologen, which is known to produce superoxide in living cells. Co-injection into citrus leaves of a virulent isolate of $X$. campestris pv. citri together with methylviologen, at a concentration causing no host tissue damage, resulted in marked inhibition of the bacterial growth in the host leaf tissue. Co-injection with SOD and catalase restored the growth of the bacteria. A spray application of methylviologen onto citrus leaves, which was sprayed at 1,7 , and $24 \mathrm{hr}$ after the bacteria were inoculated by spray, protected the leaves from occurrence of citrus canker lesions.
\end{abstract}

(Received February 10, 1987)

Key words : superoxide, Xanthomonas campestris pv. citri, ultraviolet light, methylviologen.

\section{Introduction}

Recent observations concerning $\mathrm{O}_{2}^{-}$generation by some plant tissues reacting hypersensitively to infection with phytopathogenic fungi ${ }^{6,7)}$ have suggested that $\mathrm{O}_{2}^{-}$, and its derivatives may function as direct or indirect components of resistance to the microorganisms. Hypersensitivity has also been implicated as a resistance response to phytopathogenic bacteria ${ }^{3-5,16,17)}$. Effectiveness of superoxides in killing of fungi or bacteria may be dependent on the potential of the microorganisms to protect themselves from the activated oxygen species.

An in vitro system generating $\mathrm{O}_{2}^{-}$, the xanthine-xanthine oxidase reaction, was demonstrated to kill some nonphytopathogenic bacteria ${ }^{2,11)}$. Ultraviolet light irradiation ${ }^{14)}$ or methylviologen treatment ${ }^{12)}$, which are known to generate or propagate $\mathrm{O}_{2}^{-}$in living cells, are also shown to be bactericidal. However, aerotolerant organisms may be generally

* Plant Pathology Laboratory, Faculty of Agriculture, Nagoya University, Nagoya 464, Japan 名古 屋大学農学部 
protected by superoxide dismutase and associated superoxide-catabolizing enzymes ${ }^{15)}$.

So far there is little knowledge concerning the sensitivity of phytopathogenic bacteria to superoxides. In the present experiments, sensitivity of Xanthomonas campestris pv. citri and several other phytopathogenic bacteria to superoxides was determined using a xanthine-xanthine oxidase reaction system as an extracellular $\mathrm{O}_{2}^{-}$generating system. Correlation between the sensitivity of these bacteria to $\mathrm{O}_{2}^{-12)}$ and internal generators of superoxide, ultraviolet light ${ }^{14)}$ and methylviologen ${ }^{12)}$, was examined. A brief report of this work has been published ${ }^{18)}$.

\section{Materials and Methods}

Bacteria and culture. Xanthomonas campestris pv. citri (U9-1, U6, U37 and U91CM), X. campestris pv. campestris (1076), X. campestris pv. pruni (1092), X. campestris pv. vesicatoria (1256), Erwinia herbicola (V2), Corynebacterium michiganense (C1-1-1), Agrobacterium tumefaciens (A277) and Escherichia coli (PL22) were used. U9-1, U6, U37, 1092, and V2 were kindly provided by Dr. M. Goto, C1-1-1 by Dr. A. Shirata, A277 by Dr. C. Matsui, and PL22 by Dr. H. Yamagata. U9-1CM was isolated as a colony mutant of U9-1 producing little extracellular polysaccharides. A1l bacteria used, except A227, were resistant to streptomycin, and were cultured on a potato-extract-sucrose agar medium (hot water extract from $60 \mathrm{~g}$ tuber tissue, $20 \mathrm{~g}$ sucrose and $15 \mathrm{~g}$ agar per liter) containing streptomycin at $100 \mu \mathrm{g} / \mathrm{ml}$ at $28 \mathrm{C}$ in the dark. In the case of A227 culture, streptomycin was omitted from the culture medium.

Bacterial cell suspensions were obtained by suspending bacteria, which were grown for 1 to 2 days on the above medium, in sterilized distilled water. The concentration of each bacterium was determined by correlating absorbance at 600 or $540 \mathrm{~nm}$ of the suspension with colony forming units (CFU).

Bacterial killing assay. The effects of the xanthine-xanthine oxidase (XOD) system were determined by mixing bacterial suspensions $\left(0.2 \mathrm{ml}\right.$ of $\left.1 \times 10^{6} / \mathrm{ml}\right)$ with 0.02 $\mathrm{ml}$ of XOD in $2 \mathrm{M}\left(\mathrm{NH}_{4}\right)_{2} \mathrm{SO}_{4}$ at various concentrations, $0.6 \mathrm{ml}$ of $0.2 \mathrm{M}$ potassiumphosphate buffer ( $\mathrm{pH} \mathrm{7.8)}$ and $0.38 \mathrm{ml}$ of $3.16 \mathrm{mM}$ xanthine solution. After incubation at $25 \mathrm{C}$ for $2 \mathrm{hr}$, the reaction mixture was transferred to a ice bath, diluted 200 times with cold sterilized distilled water and colony forming units determined on PSA. The assay of $\mathrm{O}_{2}^{-}$generating activity at the various concentrations of XOD involved spectrophotometric measurement of absorbance at $550 \mathrm{~nm}$ at $25 \mathrm{C}$ from 30 to $60 \mathrm{sec}$ after initiation of the reaction in reaction mixtures containing $10 \mu \mathrm{M}$ cytochrome $\mathrm{c}$ without bacteria ${ }^{13)}$.

Bacterial killing by methylviologen involved suspension of $1 \times 10^{6} \mathrm{cell} / \mathrm{s} / \mathrm{ml}$ in a solution of $1 \mathrm{~g}$ peptone and $0.5 \mathrm{~g} \mathrm{NaCl}$ per liter and varying concentrations of methylviologen. The mixture were incubated at $25 \mathrm{C}$ in the light (ca. 3,000 lux) for 3 days. After filtration of each suspension through a filter (pore size: $0.45 \mu$ ), the bacteria remaining on the filter were transferred to PSA medium to determine CFU.

Bacterial killing by ultraviolet light was assayed by spreading $0.1 \mathrm{ml}$ of bacterial suspension $\left(5 \times 10^{3}\right.$ cells $\left./ \mathrm{ml}\right)$ onto PSA. Plates were incubated at $28 \mathrm{C}$ for $2 \mathrm{hr}$, and 
then the surface was exposed to ultraviolet light from an ultraviolet lamp (Toshiba GL15) at distance of $30 \mathrm{~cm}$ for $10 \mathrm{sec}$. After growth for 3 days, bacterial colonies were counted.

Assay of superoxide dismutase activity in bacteria. A bacterial suspension $\left(1 \times 10^{8} \mathrm{cell} \mathrm{s} / \mathrm{ml}\right)$ was sonicated using a cell disrupter (Heat System Ultrasonic Inc. Model W-225 at $30 \mathrm{~W}$ for $15 \mathrm{~min}$ in an ice bath. The sonicate was filtered through a membrane (pore size: $0.45 \mu$ ) and the filtrate assayed for SOD activity according to a modified method of McCord and Fridovich ${ }^{13)}$. The reaction mixture consisted of $0.2 \mathrm{ml}$ of the test sample, $0.04 \mathrm{ml}$ of XOD in $2 \mathrm{M}\left(\mathrm{NH}_{4}\right)_{2} \mathrm{SO}_{4}, 1.2 \mathrm{ml}$ of $0.1 \mathrm{M}$ potassiumphosphate buffer containing $0.2 \mathrm{mM}$ EDTA ( $\mathrm{pH} \mathrm{7.8).} 0.2 \mathrm{ml}$ of $120 \mu \mathrm{M}$ cytochrome $\mathrm{c}$ and $0.76 \mathrm{ml}$ of $3.16 \mathrm{mM}$ xanthine solution. Concentration of XOD was adjusted to that which produced a reduction of cytochrome c of O. D. $0.030 / \mathrm{min}$ at $550 \mathrm{~nm}$. Protein content of the test sample was determined by the method of Miller ${ }^{16)}$.

Bacterial colonization in citrus leaves. A bacterial suspension of $1 \times 10^{6}$ cells/ $\mathrm{ml}$ was injected into the intracellular space of detached leaves by a syringe or sprayed on the lower surface of the leaves. The petioles of the inoculated leaves were placed into water and the leaflets were incubated in light (ca. 3,000 lux) or dark at $25 \mathrm{C}$.

For determination of bacterial colonization in leaf tissues disks (10 $\mathrm{mm}$ in diameter) were prepared from leaves which had been injected with a bacterial suspension. The tissue was homogenized in sterile distilled water and the homogenate was spread onto PSA to determine CFU.

\section{Results}

\section{Sensitivity to an exogenous $\mathrm{O}_{2}^{-}$generating system}

All Xanthomonas spp. tested were highly sensitive to the exogenous xanthine-XOD $\mathrm{O}_{2}^{-}$generating system. A few percent of each xanthomonad survived in the reaction system generating 0.95 nmoles $\mathrm{O}_{2}^{-} /$min. Less than $30 \%$ of each xanthomonad survived when 0.47 nmoles $\mathrm{O}_{2}^{-} / \mathrm{min}$ were generated. However, E. herbicola, C. michiganense and $A$. tumefaciens appeared to be more highly tolerant to both levels of $\mathrm{O}_{2}^{-}$production (Fig. 1).

The percentage of survival of isolated U9-1 of X. campestris pv. citri and of E. coli were linearly dependent on log concentration of XOD, but demonstrated different dosage effects (Fig. 2). $\mathrm{LD}_{50}$ of $X$. campestris pv. citri and $E$. coli was given by concentrations of XOD providing 0.15 and 0.95 nmoles $\mathrm{O}_{2}^{-} / \mathrm{min}$, respectively (see Fig. 5).

\section{Correlation between sensitivity to $\mathrm{O}_{2}^{-}$and ultraviolet light treatment}

The bacterial species displayed differential sensitivity to ultraviolet light. The bacteriocidal effect of ultraviolet light was significantly correlated to the survival rate upon treatment with a $0.47 \mathrm{nmole} / \mathrm{min} \mathrm{O}_{\overline{2}}$ generating system $(\mathrm{r}=0.79, \mathrm{p}<0.05)$ (Fig. 3).

\section{Correlation between sensitivity to $\mathrm{O}_{2}^{-}$and endogenous SOD activity}

Extracts from each bacterium showed substantial but variable SOD activity. SOD activity of each bacterium except E. herbicola was significantly correlated with percentage of survival against exogenous $\mathrm{O}_{2}^{-}$generating system $(\mathrm{r}=0.98, \mathrm{p}<0.05)$ (Fig. 4). E. 

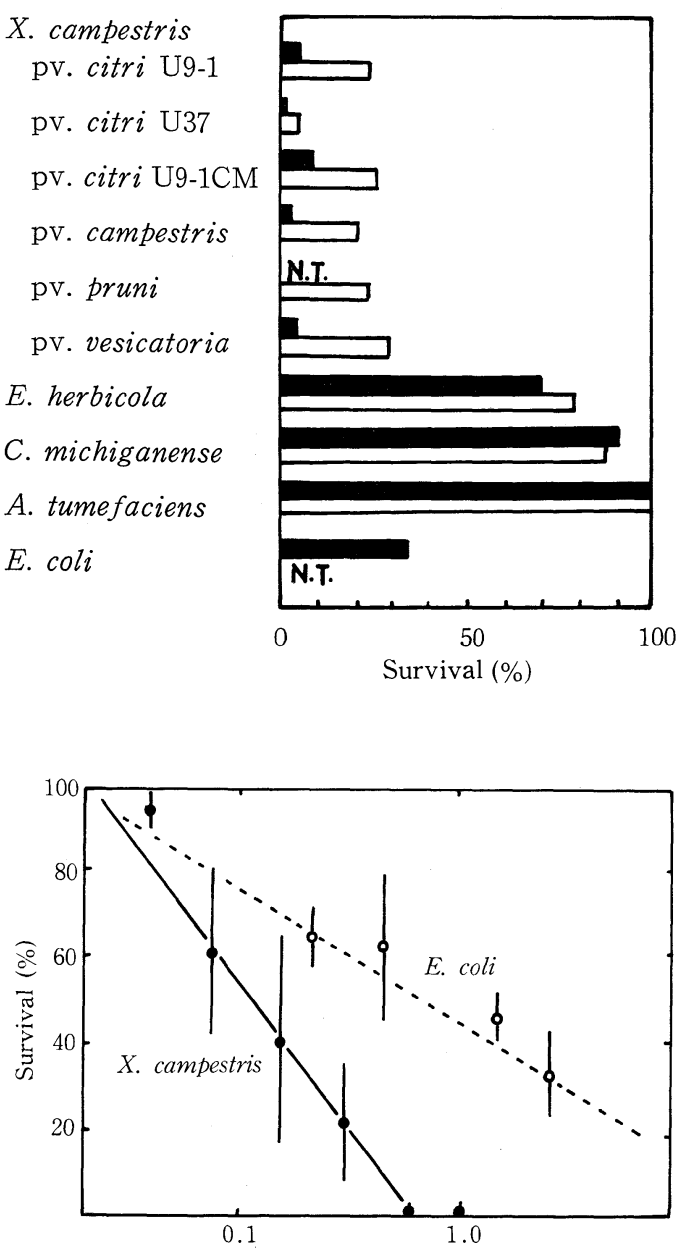

Concentration of xanthine oxidase $(\mu \mathrm{g} / \mathrm{ml})$

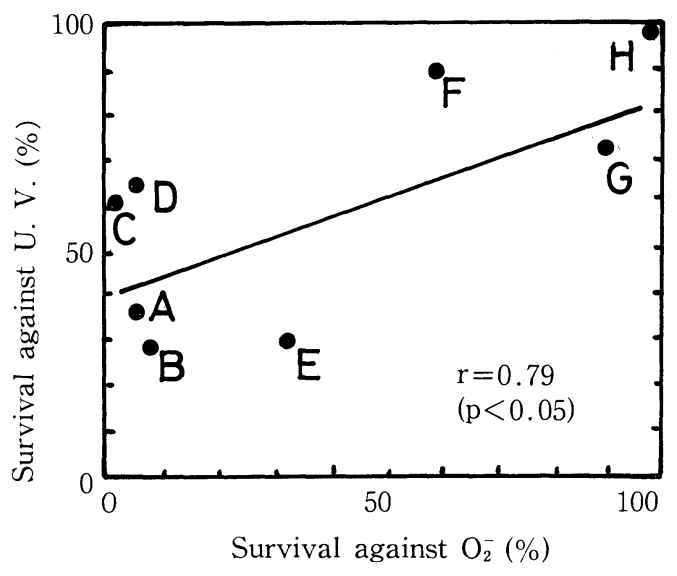

Fig. 1. Differential sensitivity of phytopathogenic bacteria to the bactericidal action of xanthine-xanthine oxidase reaction systems. Bacteria were suspended in the reaction mixtures generating $\mathrm{O}_{2}^{-}$at 0.47 (open bars) and 0.95 (filled bars) $\mathrm{nmoles} / \mathrm{min}$ (initial velocity), respectively. Bacterial killing was determined as described in Materials and Methods. An isolate of Escherichia coli was used as a reference bacterium. Survival(\%) $=$ (colony forming unit in xanthinexanthine oxidase mixture/that in the assay mixture containing no xanthine oxidase) $\times 100$. N. T. : not tested. Each value represents the average of three experiments.

Fig. 2. Killing of Xanthomonas campestris pv. citri (U9-1) (O) and Escherichia coli $(\bigcirc)$ as a function of xanthine oxidation concentration. Experiments were carried out as described in Fig. 1. except that xanthine oxidase was added at different concentrations.

Fig. 3. Correlation between bacteriocidal effects on phytopathogenic bacteria of ultraviolet light (UV) and xanthine-xanthine oxidase reaction system. Survival against UV $(\%): a / b \times 100$, where a and $b$ are populations of viable cells exposed to UV and not exposed, respectively. Survival against $\mathrm{O}_{2}^{-}(\%)$ : see Fig. 1. A : Xanthomonas campestris pv. citri (U9-1), B: X. campestris pv. citri (U9$\mathrm{CM}), \mathrm{C}: X$. campestris pv. vesicatoria, D: $X$. campestris pv. campestris, E: Escherichia coli, F : Erwinia herbicola, G. Corynebacterium michiganense, $\mathrm{H}$ : Agrobacterium tumefaciens. 
herbicola displayed very low SOD activity, but was relatively insensitive to the $\mathrm{O}_{2}^{-}$generating system.

\section{Protection by SOD and catalase of $X$. campestris pv. citri against exogenous- \\ $\mathrm{O}_{2}^{-}$}

Isolate U9-1 of $X$. campestris pv. citri was protected against a xanthine-XOD reaction system, which provide $\mathrm{O}_{2}^{-}$at a rate giving $\mathrm{LD}_{50}$, by the presence of $\mathrm{SOD}$, an enzyme scavenging $\mathrm{O}_{2}^{-}$to $\mathrm{H}_{2} \mathrm{O}_{2}$ and $\mathrm{O}_{2}$. SOD protected against bacterial killing (Fig. 5) in a linear fashion with $\log$ increases in SOD concentration from 1 to $100 \mu \mathrm{g} / \mathrm{ml}$. At a high concentration of SOD $(100 \mu \mathrm{g} / \mathrm{ml})$ less than $50 \%$ protection was achieved. Catalase (50 $\mu \mathrm{g} / \mathrm{ml}$ ) protected against the bacterial killing by almost $100 \%$ and $30 \%$ in the case of presense of SOD $(100 \mu \mathrm{g} / \mathrm{ml})$ and absense of SOD, respectively (data not shown).

When $E$. coli was incubated with a xanthine-XOD reaction system providing $\mathrm{O}_{2}^{-}$at $\mathrm{LD}_{50}$ and the same concentrations of $\mathrm{SOD}$ as those for $X$. campestris pv. citri, no protective effect was found at concentrations of SOD lower than $10 \mu \mathrm{g} / \mathrm{ml}$. Protection for $E$. coli was linearly dependent on $\log$ concentration of SOD from 10 to $100 \mu \mathrm{g} / \mathrm{ml}$. At the highest concentration $(100 \mu \mathrm{g} / \mathrm{ml})$ of SOD, nearly $100 \%$ protection was achieved in the absence of catalase (Fig. 5).

\section{Killing of $X$. campestris pv. citri by methylviologen}

The isolated U9-1 of $X$. campestris pv. citri was sensitive to methylviologen treatment. $X$. campestris pv. citri cells were killed at concentrations of methylviologen higher than $1 \mu \mathrm{M}$, depending on log concentration of the compound in the range from 0.01 to $1 \mu \mathrm{M}$
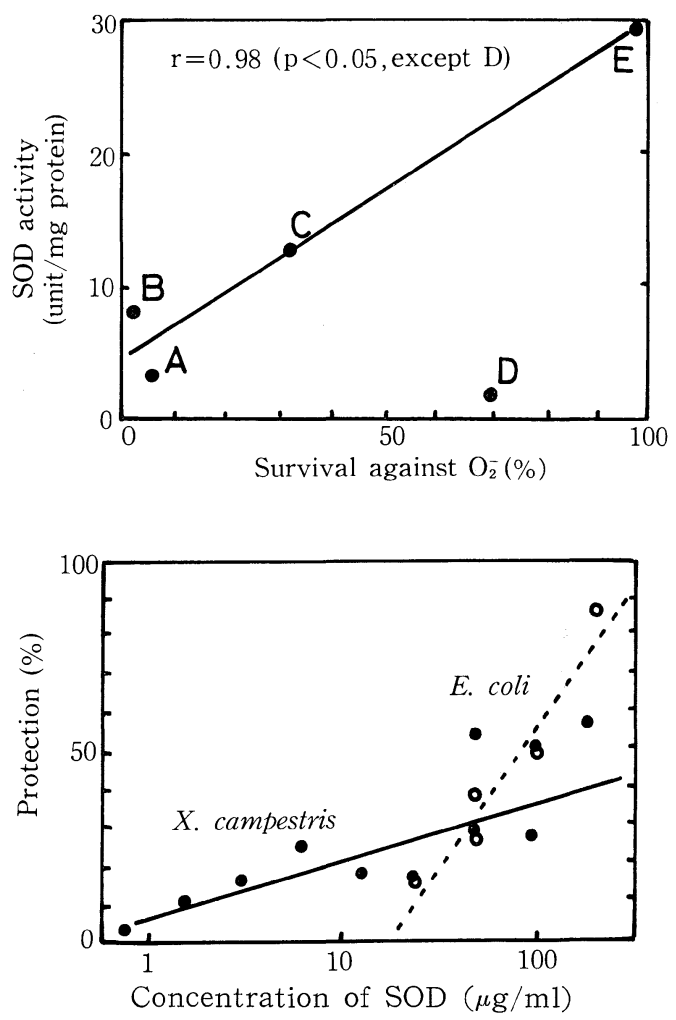

Fig. 4. Correlation between superoxide dismutase (SOD) activity in the extracts from bacteria and sensitivity to the bactericidal effect of xanthine-xanthine oxidase reaction system. SOD activity : assayed as described in Materials and Methods. Survival against $\mathrm{O}_{2}^{-}$: see Fig. 1. A : Xanthomonas campestris pv. citri (U9-1), B: X. campestris pv. pruni, C : Escherichia coli, D: Erwinia herbicola, $\mathrm{E}$ : Agrobacterium tumefaciens.

Fig. 5. Protection of Xanthomonas campestris pv. citri (U9-1) (O) and Escherichia coli (O) against xanthine oxidase as a function of superoxide dismutase (SOD) concentration. Each assay mixture contained xanthine oxidase generating 0.15 and 0.47 nmoles $\mathrm{O}_{2}^{-} / \mathrm{min}$ for giving $\mathrm{LD}_{50}$ to $X$. campestris pv. citri and E. coli, respectively, and SOD at different concentrations. 
(Fig. 6). In comparison, nearly $50 \%$ of $E$. coli survived at $1 \mu \mathrm{M}$.

To compare the sensitivity of the $X$. campestris pv. citri to methyl viologen with that of its host plant leaves (Citrus natsudaidai), $50 \mu 1$ of solution of various concentration were injected into leaves in the light. A small necrotic lesion appeared around the needle-wound applied with $10 \mu \mathrm{M}$ methylviologen, but no visible changes were observed at concentrations lower than $1 \mu \mathrm{M}$. At $100 \mu \mathrm{M}$, a large necrotic area appeared in the light while no visible changes were observed in the dark (data not shown).

Methylviologen $(1 \mu \mathrm{M})$ reduced multiplication of $X$. campestris pv. citri (U9-1) in citrus leaves by about $70 \%$ of control when inoculated in the light, and by $23 \%$ in the dark (Fig. 7). When SOD $(100 \mu \mathrm{g} / \mathrm{ml})$ or catalase $(100 \mu \mathrm{g} / \mathrm{ml})$ was coinjected, some inhibition of the methylviologen effect was observed in the light but not in the dark (Fig. 7). Co-injection with a mixture of SOD and catalase stimulated bacterial multiplication (Fig. 7) in both the light and dark to above the control values.

Inoculation of citrus leaves of $X$. campestris pv. citri produced citrus canker lesions at $10 \pm 2$ lesions/leaf $(n=25)$ around 10 days after inoculation in the light. However, no canker lesions appeared in the inoculated leaves that were subsequently sprayed with methylviologen solution at $1 \mu \mathrm{M} 1,7$, and $24 \mathrm{hr}$ after inoculation (data not shown). Spraying with methylviologen did not cause any visible changes in the citrus leaves.
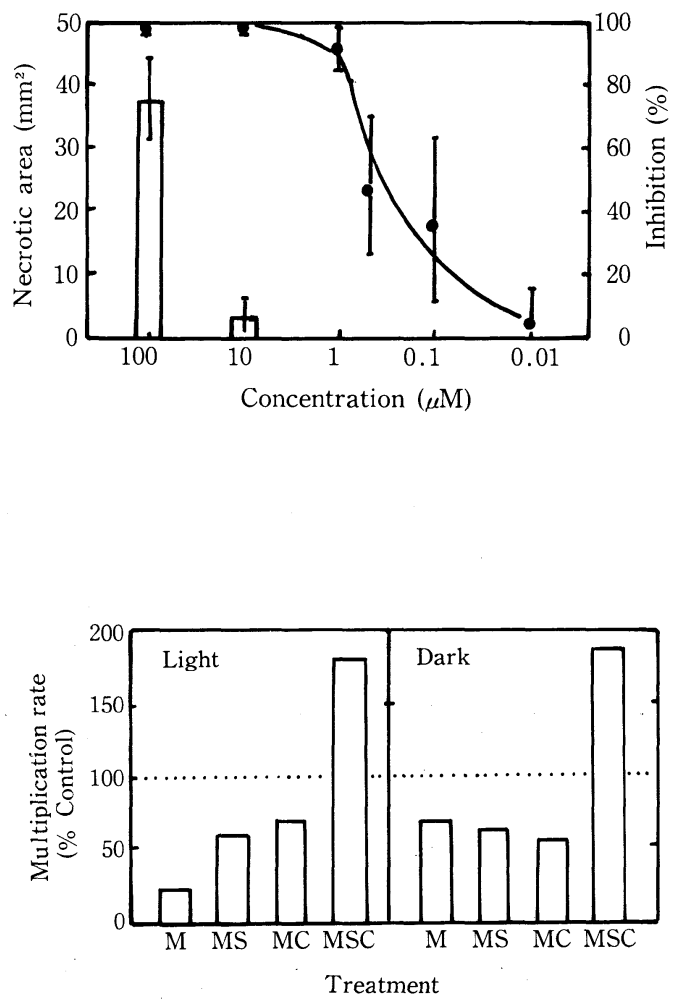

Fig. 6. Killing of Xanthomonas campestris pv. citri (U9-1) and tissue collapse of citrus leaves (Citrus natsudaidai) by methylviologen as a function of its concentrations. Necrotic area (bar): determined 3 days after application of $50 \mu 1$ of methylviologen solution $(0.01-100 \mu \mathrm{M})$ on the surface of leaf tissues with one needle wound. \% inhibition of bacteria () $: \mathrm{a} / \mathrm{b} \times 100$, where $\mathrm{a}$ and $\mathrm{b}$ are the populations of bacteria incubated in 0.1 $\%$ peptone containing $0.05 \% \mathrm{NaCl}$ for 3 days in the presence and absence of methylviologen, respectively.

Fig. 7. Effect of methylviologen on the multiplication of Xanthomonas campestris pv. citri (U9-1) in citrus leaves and recovery of its effect by superoxide dismutase (SOD) (S) and catalase (C). Bacterial suspension containing $1 \mu \mathrm{M}$ methylviologen $(\mathrm{M})$ was injected together with SOD $(100 \mu \mathrm{g} / \mathrm{ml})(\mathrm{MS})$, catalase $(100 \mu \mathrm{g} /$ $\mathrm{ml})(\mathrm{MC})$ or SOD plus catalase $(100 \mu \mathrm{g}$ $/ \mathrm{m} 1$, each) (MSC). The inoculated leaf disks were incubated for 3 days in the light or dark at $28 \mathrm{C}$. Multiplication rate $(\%$ control) $: \mathrm{a} / \mathrm{b} \times 100$, where $\mathrm{a}$ and $b$ are increased population of viable bacteria in leaf tissues inoculated with or without the enzymes, respectively. 


\section{Discussion}

The bactericidal effect of $\mathrm{O}_{2}^{-}$produced by xanthine-XOD reaction ${ }^{9,10)}$ was first demonstrated by Green and Pauli ${ }^{11}$. In the present experiments phytopathogenic bacteria Xanthomonas spp. were shown to be more sensitive to this $\mathrm{O}_{2}^{-}$generating system, than Erwinia, Corynebacterium and Agrobacterium isolates.

The nature of the activated oxygen species active as a bactericide is uncertain. With E. coli, the inability of SOD to protect against $\mathrm{O}_{2}^{-}$has led to the proposal that $\mathrm{H}_{2} \mathrm{O}_{2}$ may be the bactericidal agent ${ }^{2)}$. The present experiments also showed that SOD at low concentrations did not protect against the killing of E. coli, although complete protection was observed at high concentrations. $X$. campestris pv. citri, although it was more sensitive to xanthine-xanthine oxidase reaction system, was partially protected from killing by SOD even at high concentrations. These data suggest that the killing of $X$. campestris pv. citri may take place by a different mechanism from that for $E$. coli. The great protection conferred on $X$. campestris pv. citri by a mixture of SOD and catalase as well as the partial protection by SOD or catalase alone, indicates that killing may be partly mediated by $\cdot \mathrm{OH}$, a products of a reaction between $\mathrm{O}_{2}^{-}$and $\mathrm{H}_{2} \mathrm{O}_{2}$, in addition to $\mathrm{O}_{2}^{-}$ or $\mathrm{H}_{2} \mathrm{O}_{2}$ alone, or both.

A positive correlation between sensitivities of phytopathogenic bacteria to the exogenous xanthine-XOD reaction system and ultraviolet light irradiation, which generate $\mathrm{O}_{2}^{-}$ within the cell ${ }^{14}$, was revealed. These studies also demonstrated differences between the bacterial phytopathogens in sensitivity to superoxide. A negative correlation of SOD activity in extracts from the bacteria with sensitivity to the xanthine-XOD reaction system sugggests that the differential sensitivity to superoxides among bacteria may be dependent on their activity to catabolize superoxides. However, one isolate of Erwinia showed very low activity of SOD although it was relatively tolerant to the xanthine-XOD reaction system and ultraviolet light. Its tolerance to superoxide presumably depends on mechanisms other than SOD to escape from the toxicity of superoxides.

As expected from the sensitivity of $X$. campestris pv. citri to superoxides, growth of this species was inhibited by methylviologen, which is known to propagate $\mathrm{O}_{2}^{-}$by coupling with endogenously generated $\mathrm{O}_{2}^{-}{ }^{8}$. The bacterium was nearly 100 fold more sensitive to methylviologen than leaves of its susceptible host, citrus, even in light when $\mathrm{O}_{2}^{-}$ can be extensively propagated by coupling with photosynthetic electron transfer. Indeed, the multiplication of $X$. campestris pv. citri in host leaves was greatly inhibited by injection with the methylviologen although there was no visible damage to the host tissues. The reduction of the methylviologen-inhibition of bacterial growth by SOD and catalase suggested that bactericidal levels of superoxides were being generated in host leaf tissues. A greater reduction of it by mixture of them than each suggested that an active superoxide species may be $\cdot \mathrm{OH}$ produced by reaction between $\mathrm{O}_{2}^{-}$and $\mathrm{H}_{2} \mathrm{O}_{2}$ in situ. The observed protection of citrus leaves from incidence of citrus canker by spraying methylviologen subsequent to $X$. campestris pv. citri inoculation, also supports $\mathrm{O}_{2}^{-}$production in leaf tissue. The exact mechanism of bactericidal effect in leaf tissue 
treated with methylviologen remain to be further investigated. The superoxide-sensitive nature of xanthomonads may possibly be utilized in control measures by applying superoxide-producing agents to plant tissues at concentrations which are bactericidal but not phytotoxic.

The authors wish to thank Drs. M. Goto, C. Matsui, A. Shirata and H. Yamagata for kind supply of the bacteria isolates and Dr, Anne J. Anderson for her critical review of this manuscript.

\section{Literature cited}

1. Atkinson, M. M., Huang, J. and VanDyke, C. G. (1981). Physiol. Plant Pathol. 18:1-5.

2. Babior, B. M., Curnutte, J. T. and Kipnes, R. S. (1975). J. Lab. Clin. Med. 85:235-243.

3. Bonatti, P. M., Dargeni, R. and Mazzucchi, U. (1979). Phytopath. Z. $96: 302-312$.

4. Croschwaite, L. M., Sakai, W. S. and Patil, S. S. (1979). Ibid. $95: 24-37$.

5. Daub, M. E. and Hagedorn, D. J. (1980). Phytopathology $70: 429-436$

6. Doke, N. (1983). Physiol. Plant Pathol. $23: 345-357$.

7. Doke, N. (1983). Ibid. $23: 369-367$.

-8. Fischer, H. K. (1976). Lif. Sci. $19: 421-426$.

9. Fridovich, I. (1972). Acc. Chem. Res. $5: 321-326$.

10. Fridovich, I. and Handler, P. (1958). J. Biol. Chem. $233: 1518-1585$.

11. Green, D. E. and Pauli, R. (1943). Roc. Soc. Biol. Med. $54: 148-150$.

12. Hossan, H. M. and Fridovich, I. (1979). J. Biol Chem. $254: 10846-10852$.

13. McCord, M. and Fridovich, I. (1969). Ibid. 244:6049-6055.

14. McCord, J. M. and Fridovich, I. (1972). Photochem. Photobiol. 17 : 115-121.

15. McCord, J. M., Keele, B. B. Jr. and Fridovich, I. (1971). Proc. Nat. Acad. Sci. $68: 1024-1072$.

16. Miller, G. L. (1959). Anal. Chem. $31: 964$.

17. Rose, M. S., Smith, L. L. and Wyatt, I (1976). Biochem. Pharmacol. $25: 1763-1767$.

18. Shibata, T. and Doke, N. (1984). Ann. Phytopath. Soc. Japan $50: 127$ (abstract in Japanese).

\section{和 文 摘 要}

道家紀志・柴田俊浩: Xanthomonas campestris pv. citri および数種の植物病原細菌の活性酸素, 紫外線お よびメチルビオロジェンに対する感受性

Xanthomonas campestris pv. citri, pv. campestris, pv. pruni および pv. vesicatoria $\mathrm{O}_{2}^{-}$生成系であるキ サンチン一キサンチン酸化酵素反応系に混合すると, 強い殺菌効果がみられた。しかし, 他に供試した Agrobacterium tumefaciens, Erwinia herbicola, Corynebacterium michiganense はその $\mathrm{O}_{2}^{-}$生成系に対して比較的 耐性であった。各々の細菌の $\mathrm{O}_{2}^{-}$生成系に対する感受性は, 紫外線感受性と正の相関を示し, また, 細菌のス ーパーオキシドジスムターゼ活性と負の相関を示した。X. campestris pv. citri に対する殺菌作用は, キサン チン酸化酵素の対数濃度と直線的相関を示し，その反応系に加えたスーパーオキシドジスムターゼ及びカタラ 一ゼによって部分的に回復した。本菌は生体内で $O_{2}^{-}$を增産するメチルビオロジェンに強い感受性を示し, 本 菌を宿主植物のカンキツ葉に薬害を与えない濃度のメチルビオロジェンと共に注射接種すると, 顕著な増殖抑 制効果がみられた。また, 本菌をスプレー接種したカンキツ葉に, 接種後一日以内にての薬剂をスプレー処理 すると, 発病が顕著に抑制された。 